\title{
Reducing the Fire Hazard of Wooden Structures
}

\author{
Asgat Gazizov ${ }^{1,2, a}$, Aisylu Sagitova ${ }^{1, b^{*}}$ and Anton Krasnov ${ }^{1}$ \\ ${ }^{1}$ Ufa State Petroleum Technological University, 1 Kosmonavtov str., Ufa, Republic of \\ Bashkortostan, 450064, Russia \\ 2Ural State Forest Engineering University, 37 SibirskyTrakt, Yekaterinburg, 620100, Russia \\ aashatgaz@mail.ru; bsagitovaais@gmail.com
}

\begin{abstract}
Keywords: Fire Danger, Wooden Structures, Fire Protection, Fire-Retardant Composition
\end{abstract}

\begin{abstract}
Increasing the fire resistance of wooden structures is relevant because of their increased flammability. The article describes an experimental study using NEOMID flame retardant paint and silica powder as a flame retardant for wooden structures. According to the results of the experiment, a group of fire-retardant effectiveness of the tested fire-retardant composition was established with different methods of its use.
\end{abstract}

\section{Introduction}

Wood is one of the most common materials in the construction of buildings and structures for various purposes. Increased flammability of wooden structures is one of the main problems in the fire safety system of buildings. The main task is to reduce the fire hazard of wooden structures and increase their fire resistance [1].

Fireproofing of wooden building structures using coatings is the simplest method. Fire-retardant coatings protect wooden structures from fire, can release gases and water vapor during heating, which phlegmatize the flame and prevent combustion. Unlike impregnation, the use of fireretardant coatings allows to provide the I group of fire protection of large structures, the autoclave impregnation of which is impossible to obtain the same group of fire protection [2-5].

\section{Methods and results of research}

For the study, wood samples in the form of rectangular bars with a cross section of 50x50mm were used, the deviation from the dimensions did not exceed $1 \mathrm{~mm}$. Each bar before processing was weighed on electronic scales.

The fire retardant composition was NEOMID flame retardant acrylic paint. Fire retardant paint has a certificate of conformity No. C-RU.KB03.V.00216 with a validity period from 14.11.2017 to 13.11 .2022 .

Silicon dioxide (silica, $\mathrm{SiO}_{2}$ ) [6] was also used as a fire-retardant composition together with paint.

A layered flame retardant was applied to the wood samples and dried at room temperature (Fig. 1). 


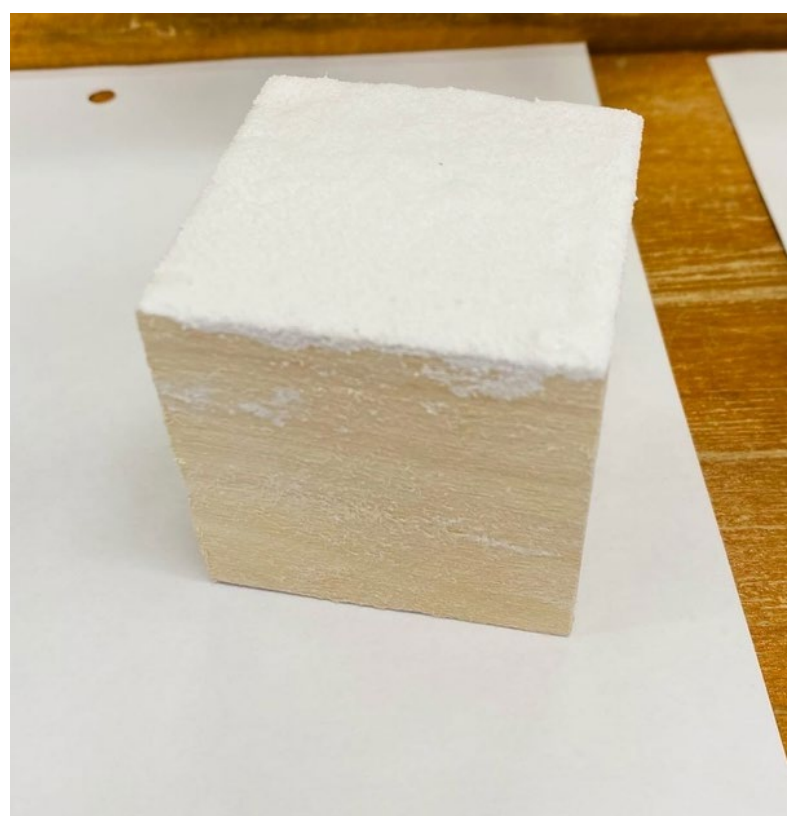

Fig. 1. A sample coated with a fire retardant

The total fire-retardant composition flow rate applied to the wood sample was determined by summing the flow rates after each layer was applied over the surface area of the sample (Table 1).

Table 1. Sample mass data before and after treatment

\begin{tabular}{|c|c|c|c|c|}
\hline $\begin{array}{l}\text { Sample } \\
\text { number }\end{array}$ & Drying time, $[\mathrm{h}]$ & Number of layers & $\begin{array}{c}\text { Weight of bar } \\
\text { before treatment, } \\
{[\mathrm{g}]}\end{array}$ & $\begin{array}{l}\text { Weight of bar } \\
\text { after treatment, } \\
{[\mathrm{g}]}\end{array}$ \\
\hline 1 & \multirow{9}{*}{24} & 1 & 49,5 & 50,0 \\
\hline 2 & & 2 & 60,5 & 61,0 \\
\hline 3 & & 3 & 50,0 & 50,5 \\
\hline 4 & & $\begin{array}{l}1 \text { layer }+ \text { sprinkling } \\
\text { silica } 1 \text { time }\end{array}$ & 60,5 & 62,5 \\
\hline 5 & & $\begin{array}{c}2 \text { layers }+ \\
\text { sprinkling silica } 1 \\
\text { time }\end{array}$ & 61,0 & 62,5 \\
\hline 6 & & $\begin{array}{c}3 \text { layers }+ \\
\text { sprinkling silica } 1 \\
\text { time }\end{array}$ & 56,5 & 57,5 \\
\hline 7 & & $\begin{array}{l}1 \text { layer }+ \text { sprinkling } \\
\text { silica } 2 \text { times }\end{array}$ & 58,0 & 58,5 \\
\hline 8 & & $\begin{array}{c}2 \text { layers }+ \\
\text { sprinkling silica } 1 \\
\text { time }\end{array}$ & 51,5 & 52,0 \\
\hline 9 & & $\begin{array}{c}3 \text { layers }+ \\
\text { sprinkling silica } 1 \\
\text { time }\end{array}$ & 66,0 & 67,0 \\
\hline
\end{tabular}


After 24 hours of drying, fire tests were carried out on the Ceramic Pipe unit of samples No. 19. The samples were exposed to a temperature of $200^{\circ} \mathrm{C} \pm 5^{\circ} \mathrm{C}$ for 2 minutes (Fig. 2).

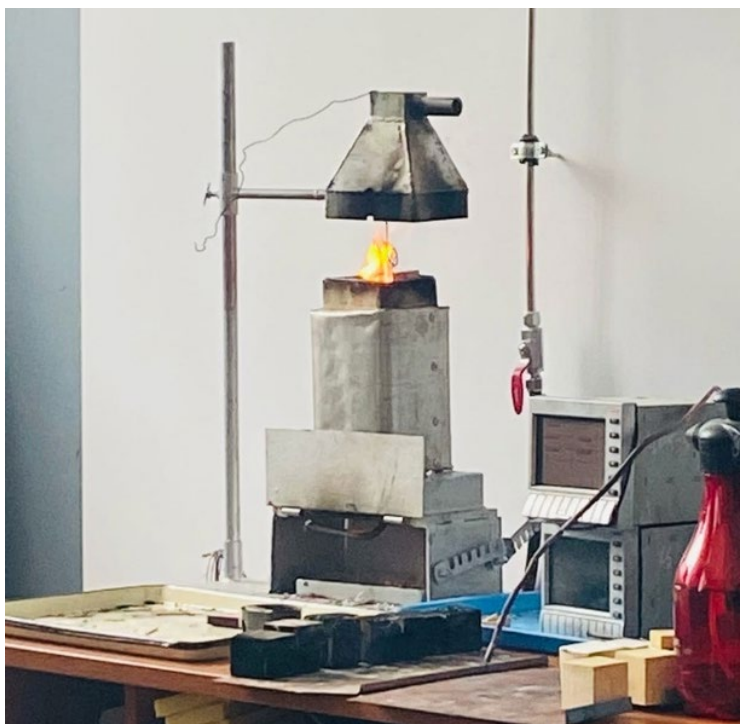

Fig. 2. Sample burning

After cooling the sample, the remainder of the sample was removed from the ceramic box (Fig. 3).

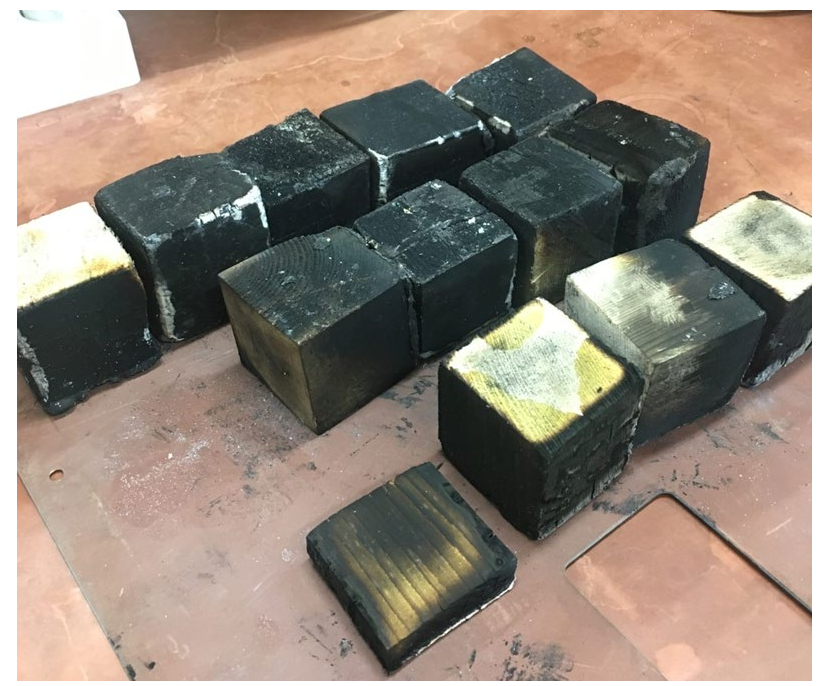

Fig. 3. Samples after incineration

The composition flow rate, after each treatment, was determined by weight from the mass difference of the sample before and after fire-retardant composition application. Weighing of the coated samples was carried out after stopping the runoff from the surface of the uneaten solution. At the end of the sample, fire-retardant composition residues were removed with filter paper.

Total absorption $\mathrm{R}, \mathrm{kg} / \mathrm{m}^{3}$, was determined by formula (1):

$$
R=\frac{m_{1}-m_{2}}{V} .
$$

Where $\mathrm{m}_{1}$ is the mass of the sample after coating, $\mathrm{kg} ; \mathrm{m}_{2}$ - sample weight before coating, $\mathrm{kg}$; $\mathrm{V}$ - sample volume, $\mathrm{m}^{3}$. 
Weight loss of $\mathrm{P}_{\mathrm{i}}$ samples, \%, was calculated (Table 2) by formula (2):

$$
P_{i}=\frac{\left(m_{1 i}-m_{2 i}\right) * 100}{m 1 i}
$$

Where $\mathrm{m}_{1 \mathrm{i}}$ - is the mass of the sample before the test, $\mathrm{g} ; \mathrm{m}_{2 \mathrm{i}}$ - is the mass of the sample after the test, $\mathrm{g}$; $\mathrm{i}$ - is the sample number.

After the test, the arithmetic mean of the weight loss of the samples tested was determined (Table 2) by formula $(3,4)$.

$$
\begin{aligned}
& \left|P_{\text {avrg }}-P_{i}\right| \leq 3 \text { при } P_{\text {avrg }} \leq 9 \\
& \left|P_{\text {avrg }}-P_{i}\right| \leq 5 \text { при } 9<P_{\text {avrg }} \leq 25
\end{aligned}
$$

Where $\mathrm{P}_{\mathrm{avrg}}$-is the arithmetic mean weight loss of the nine samples tested, $\% ; \mathrm{P}_{\mathrm{i}}$ - is the weight

\begin{tabular}{|c|c|c|c|c|c|c|}
\hline \multirow[t]{2}{*}{$\begin{array}{l}\text { Sample } \\
\text { number }\end{array}$} & \multicolumn{3}{|c|}{ Sample weight, [g] } & \multicolumn{2}{|c|}{$\begin{array}{c}\text { Loss of sample } \\
\text { weight }\end{array}$} & \multirow{2}{*}{$\begin{array}{l}\text { Modulus of } \\
\text { arithmetic mean } \\
\text { weight loss, [\%] }\end{array}$} \\
\hline & $\begin{array}{l}\text { Before } \\
\text { treatment }\end{array}$ & $\begin{array}{c}\text { After } \\
\text { treatment }\end{array}$ & $\begin{array}{c}\text { After } \\
\text { combustion }\end{array}$ & {$[\mathrm{g}]$} & {$[\%]$} & \\
\hline 1 & 49,5 & 50,0 & 40,5 & 9,5 & 19,0 & 7,14 \\
\hline 2 & 60,5 & 61,0 & 54,0 & 7,0 & 11,48 & 0,38 \\
\hline 3 & 50,0 & 50,5 & 45,0 & 5,5 & 10,89 & 0,97 \\
\hline 4 & 60,5 & 62,5 & 54,0 & 8,5 & 13,6 & 1,74 \\
\hline 5 & 61,0 & 62,5 & 57,0 & 5,5 & 8,8 & 3,06 \\
\hline 6 & 56,5 & 57,5 & 51,5 & 6,0 & 10,43 & 1,43 \\
\hline 7 & 58,0 & 58,5 & 55,0 & 3,5 & 5,98 & 5,88 \\
\hline 8 & 51,5 & 52,0 & 44,0 & 8,0 & 15,38 & 3,52 \\
\hline 9 & 66,0 & 67,0 & 59,5 & 7,5 & 11,19 & 0,67 \\
\hline \multicolumn{3}{|c|}{ Arithmetic mean: } & 51,16 & & 11,86 & \\
\hline
\end{tabular}
loss value of one of the nine samples tested, $\%$.

Table 2. Results of the obtained calculations

Based on the results of experiments, a fire-retardant efficiency group was established for each sample of the tested fire-retardant composition (Table 3). As such, mass loss for our samples is not more than $9 \%$, which corresponds to the I fire-retardant efficiency group.

Table 3. Fireproofing group of samples

\begin{tabular}{|c|c|}
\hline Sample number & Fire protection group \\
\hline 1 & I \\
\hline 2 & I \\
\hline 3 & I \\
\hline 4 & I \\
\hline 5 & I \\
\hline 6 & I \\
\hline 7 & I \\
\hline 8 & I \\
\hline 9 & I \\
\hline
\end{tabular}



4).

Let us present the dependence of the mass loss of the tested samples in the form of a graph (Fig.

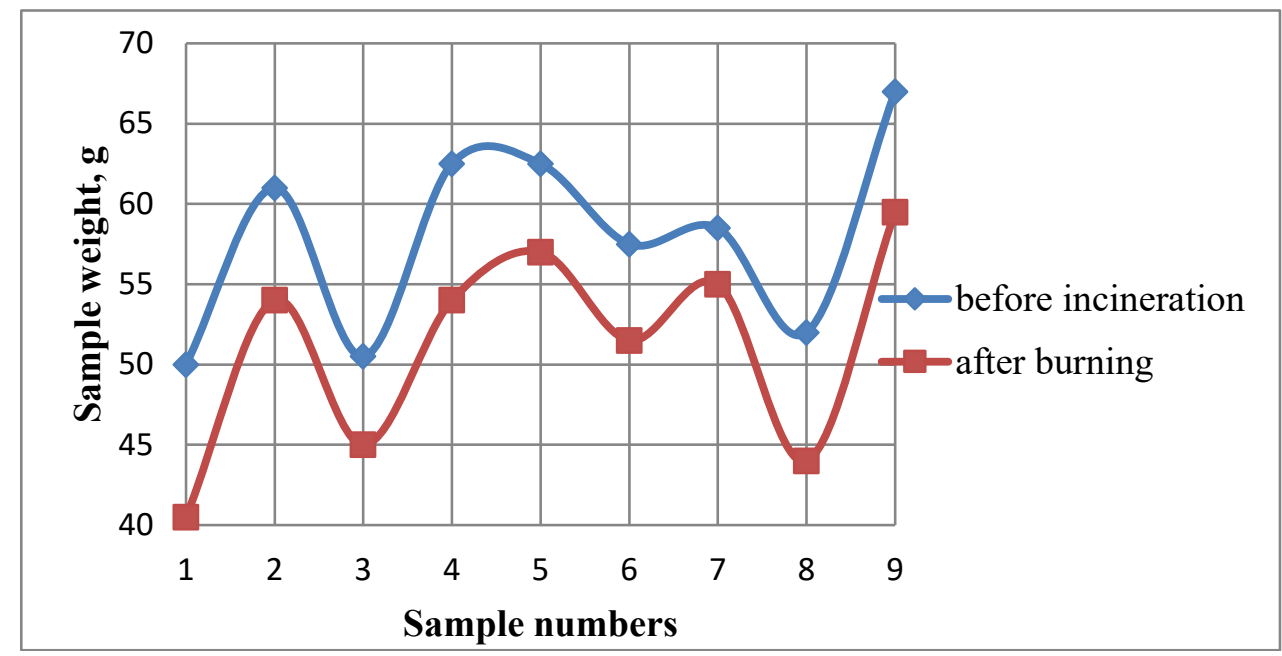

Fig. 4. Plot of weight loss for each sample

\section{Conclusion}

In the course of the study, it was found that all samples coated with fire-retardant paint and silicon dioxide belong to group I of fire-retardant efficiency. Thus, an fire-retardant composition consisting of a flame retardant acrylic decorative NEOMID paint and silica is an effective means for increasing the fire resistance of wooden structures.

Sample No. 7 has the highest fire retardant efficiency of all test samples, since this sample has a minimum weight loss. Thus, treatment of wood 1 with a layer of flame retardant acrylic decorative paint NEOMID + sprinkling with silica twice provides the highest fire retardant efficiency of the nine test pieces.

\section{References}

[1] F. Sh. Khafizov, A. M. Gazizov and D. F. Muratov, Fire Retardants Application for Wood Material, Oil and Gas Business, number 2, 2019, p. 16-31. https://doi.org/10.17122/ogbus-20192-16-31

[2] A.M. Gazizov, O.V. Kuznetsova, A.A. Sharafutdinov and K.M. Shaimuhametova, Improvement of fire retardant properties of wood materials, IOP Conference Series: Materials Science and Engineering, Volume 919 (2020). https://doi.org/10.1088/1757-899X/919/6/062014 [3] A. Y. Korolchenko and O. N. Korolchenko, Fire protection equipment, Moscow, 2006, p 258.

[4] A.M. Gazizov, E.V. Popova, O.V. Kuznetsova and A.A. Akhmadullin, Method of increasing the fire resistance of wood IOP Conference Series: Materials Science and Engineering, Volume 971(3) (2020). https://doi.org/10.1088/1757-899X/971/3/032029

[5] A. A. Leonovich and G. B. Shalun, Fire Protection of Wood Boards and Laminated Plastics, Moscow: Lesnaya promyshlennost Publ., 1974.

[6] A. M. Gazizov, I. I. Dudnichenko and F. Sh. Khafizov, Application of silica filler to increase fire resistance of wood, Oil and Gas Business, number 1, 2020, p. 42-52.

https://doi.org/10.17122/ogbus-2020-1-42-52 